\title{
AN OVERVIEW ON POTENTIAL HYDROMETALLURGICAL PROCESSES FOR SEPARATION AND RECOVERY OF MANGANESE
}

\author{
Sanghamitra Pradhan, Muskan Ram, Sujata Mishra* \\ Department of Chemistry, Institute of Technical Education and Research (FET), \\ Siksha 'O' Anusandhan Deemed to be University, Khandagiri Square, \\ Bhubaneswar-751030, Odisha, India
}

Received 10.09.2020

Accepted 10.11.2020

\begin{abstract}
With rapid economic progress worldwide, the search for new resources for materials has become a priority due to mineral resource depletion. Enhanced requirements for manganese alloys and compounds for several commercial applications created a desperate demand for manganese recovery technologies from primary as well as secondary resources. The future demand for manganese alloys and compounds is expected to increase. The growing need of electrolytic manganese dioxide (EMD) for different battery usage in automobile and energy sectors could create a gap in the supply and demand of manganese. There is an urgent necessity for eco-friendly and efficient technologies to boost the production of manganese from low-grade ores as well as postconsumer products. The framework of effective leaching processes and proper solvent extraction techniques for the recovery of manganese could be a novel pathway to get a clean, green and healthy environment for a sustainable future in the automotive and energy segment where this metal has a significant contribution.
\end{abstract} products.

Keywords: manganese; ores; leaching; solvent extraction; post-consumer

\section{Introduction}

Manganese $(\mathrm{Mn})$ is one of the $3 \mathrm{~d}$ transition metals, which plays a vital role in human life and industries. The need for manganese ore has increased significantly due to an upsurge in the fabrication of steel [1]. It is an effective metal used in metal alloys, such as in stainless steel. Manganese has no satisfactory substitute in its major applications in metallurgy and is the fourth most-traded metal worldwide. Due to its diverse applications, the extraction of manganese is vital from ores and secondary resources with the aid of an

${ }^{*}$ Corresponding author: Sujata Mishra, drsujatamishra97@gmail.com, sujatamishra@soa.ac.in 
economically viable process. The $3 \mathrm{~d}$ series of metals have an extensive range of commercial demands in various sectors [2]. They can behave both as thermal and electrical conductors due to their malleable and ductile nature. The unique property of transition metals to form coordination complexes has initiated the development of metalbased drugs with an encouraging pharmacological application. From the point of view of human health, manganese serves as an important element to carry out metabolic and vital antioxidant activities [3]. The extensive use of manganese in different sectors, such as steel production, dyes, and batteries, makes it a strategic element. It is reported that nineteen million metric tons of manganese were consumed in 2017 , with a global production of twenty million metric tons. The demand for manganese has been anticipated to reach 28.2 million metric tons by 2022, with a decline in manganese production to 19.1 million metric tons [4]. The growing exploitation of these metals and their consequent expulsion is piling on in the environment with worrying concentrations. In the present scenario, the industries are in search of implementing novel, effective, and environmentfriendly methods for recycling of resources due to the massive depletion of natural mineral sources [5]. A comprehensive outlook on various methods used for the increasing manganese concentration in ores has been summarized by Singh et al. [6]. Manganese occurs in nature and hardly exists in a pure and elemental state. It is generally distributed in the terrestrial crust and is often found allied with iron ores in a comparatively smaller amount. The polymetallic sea nodules are also being considered as an important source of manganese alloy [7]. The ores of $\mathrm{Mn}$ are generally categorized as chemical, nonmetallurgical, and metallurgical [8]. Higher than $80 \%$ of the high-grade manganese ore i.e. $>35 \%$ manganese, is mined in India, Australia, Brazil, South Africa, Gabon, China and in Commonwealth of Independent States (CIS). Manganese is distributed in the earth's crust as approximately $0.1 \%$ and is found in more than 100 minerals. Carbonates, oxides, and silicates are the most vital among the manganese-containing minerals. Manganese occurs at the bottom of the ocean and also present as a natural trace element in crude oil. Pyrolusite $\left(\mathrm{MnO}_{2}\right)$, manganite $(\mathrm{MnO}(\mathrm{OH}))$, braunite $\left(3 \mathrm{Mn}_{2} \mathrm{O}_{3} \cdot \mathrm{MnSiO}_{3}\right)$, and hausmannite $\left(\mathrm{Mn}_{3} \mathrm{O}_{4}\right)$ are prominent manganese ores which are mostly found in India and African countries. The percentage of manganese content in the manganese minerals are presented in Table 1 [9].

Table 1. Principal manganese ores with the percentage of manganese content.

\begin{tabular}{ll}
\hline Manganese ores & Mn, wt.\% \\
\hline Manganite & 62.5 \\
Pyrolusite & 63.2 \\
Braunite & 66.6 \\
Hausmannite & 72 \\
\hline
\end{tabular}


The less important manganese ores are rhodochrosite $\left(\mathrm{MnCO}_{3}\right)$ and rhodonite $\left(\mathrm{MnSiO}_{3}\right)$. The data released by United states geological survey in 2014 for distribution of manganese ores all over the world has been represented in Fig.1 [10].

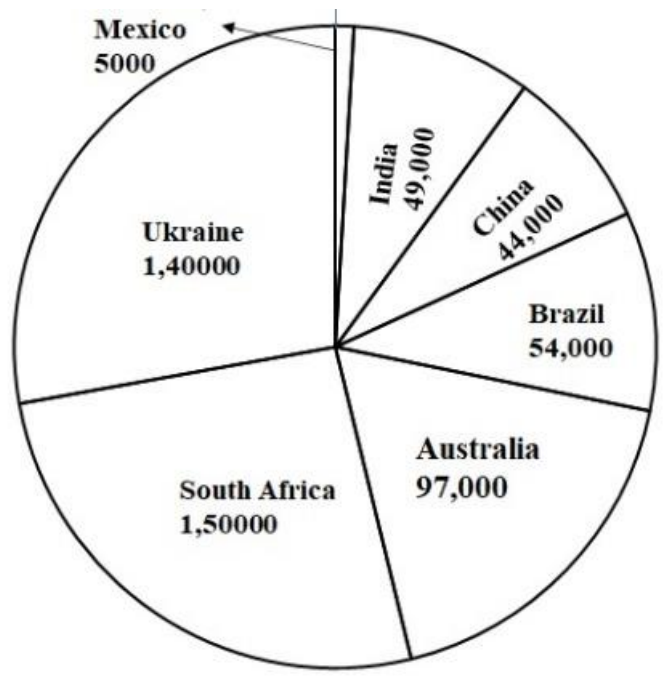

Fig. 1. Reserves of Manganese ores in metric tons in different countries.

In the last few years, the advancements of power technologies employing batteries as a power source have increased the quantity of spent batteries that are reaching landfill sites. The alkaline batteries contain manganese dioxide as the cathodic material. The concentration of manganese in various types of battery wastes are enlisted below in Table 2 [11]. The disposition of exhausted zinc- $\mathrm{MnO}_{2}$ batteries has been a major environmental concern [12]. The rise in demand for manganese and consequent increase in the gap between supply and demand has led to a price hike of both manganese ores and manganese alloys $[13,14]$.

Table 2. Manganese concentration in $\mathrm{mg} / \mathrm{kg}$ in different types of battery wastes.

\begin{tabular}{llllll}
\hline Alkaline & Ni-MH & Li-M & Li-ion & Ni-Cd & Zn-Cd \\
\hline 329,700 & 15,915 & 513 & 30.5 & 494 & 265,720 \\
\hline
\end{tabular}

This review pronounces a detailed report on potential hydrometallurgical processes such as leaching and solvent extraction used to recover manganese from ores and secondary resources such as diverse types of battery wastes. A summary of various leaching processes and the use of different organic extractants have been presented. The recent developments in the hydrometallurgical recycling strategies and challenges associated with these have also been discussed. 


\section{Recovery from ores}

Hydrometallurgical processes include leaching and extraction of metals from ores and different secondary resources from aqueous solutions using a number of extracting agents. This option is highly commercialized because of the high pureness of the resulted metal and the consumption of less energy [15]. The scheme for recovery of manganese from ores through leaching and solvent extraction is represented in Fig. 2.

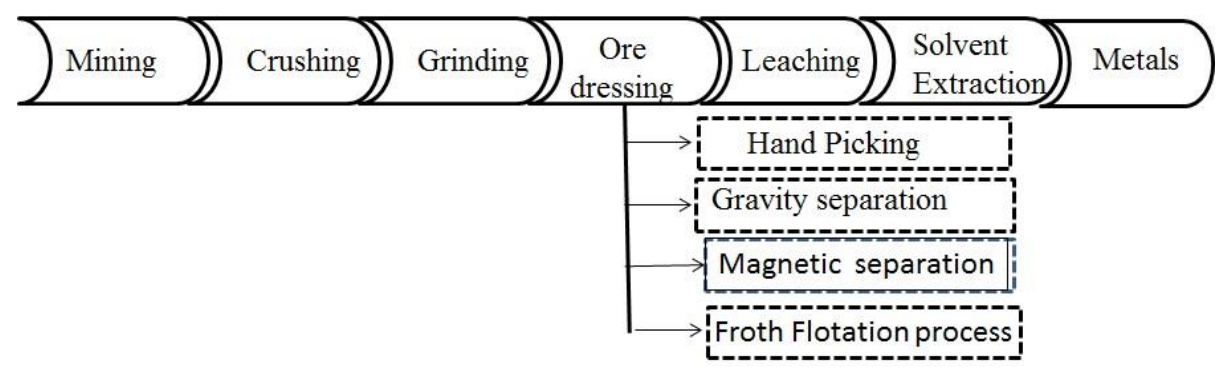

Fig. 2. Schematic representation of recovery of manganese from ores using a hydrometallurgical route.

\section{a. Leaching}

Leaching is a process extensively adopted in extractive studies where chemicals are used to treat the ores to obtain soluble salts of valuable metals. Chemicals, both organic and inorganic, are utilised as reducing agents in the leaching process. To make this process eco-friendlier and more cost effective, new low-cost reductants such as carbohydrates [16], molasses [17], sawdust [18], and waste paper [19] are being utilised as reducing agents. Following the traditional hydrometallurgical technique, the recovery of Mn (II) has been scrutinised from low-grade manganese ores by leaching in sulphuric acid medium without using reducing agents. Different parameters that affect the leaching, such as dissolution time, the concentration of sulphuric acid, have been examined. Under the optimal leaching condition, the leaching efficiency has been recorded to be $96.73 \%$ [20]. The use of low-grade manganese ores has been considered for the leaching and extraction of manganese due to the inadequacy of high - quality manganese ores.

$Y$. Zhang et al. [21], have performed roasting using sulphur as reductant prior to the leaching process; thus, the leaching was carried out in an acidic medium. Sulphur reduces manganese oxide ores to form different oxides of manganese and under the optimised conditions, 96\% Mn has been leached effectively. Dundua and Agniashvili [22], recovered manganese from the residual slimes using $\mathrm{FeSO}_{4}$ as the leaching agent in the electrochemical production of manganese dioxide. Consequently, leaching of $98.3 \%$ for manganese from a manganese oxide ore was obtained by $C$. Zhang et al. with the use of EDTA to manganese molar ratio $1: 1$ at $\mathrm{pH} 5.5,70{ }^{\circ} \mathrm{C}$ and liquid to solid ratio of $3: 1$. Finally, $\mathrm{Mn}_{3} \mathrm{O}_{4}$ was synthesized as a result of the roasting of Mn- EDTA complex [23].

E.K. Addai et al. have carried out reductive leaching of a mixture of manganese carbonate and pyrolusite ores in sulphuric acid with ferrous carbonate as reductant. The influence of different parameters like leaching time, temperature, the concentration of $\mathrm{H}_{2} \mathrm{SO}_{4}$ were studied. It has been observed that $96 \%$ of $\mathrm{Mn}$ has been extracted under the optimal condition when the ratio of manganese carbonate and pyrolusite was 5:1 by weight [24]. The reductive leaching of pyrolusite ore has also been performed by 
Ekmekyapar et al. using sawdust as a reductant to produce manganese sulphate. It was observed that the leaching efficiency enhanced with an increase in the concentration of $\mathrm{H}_{2} \mathrm{SO}_{4}$, sawdust amount, leaching time, and temperature. And finally, manganese in the form of manganese sulphate was recovered through evaporative crystallization of leach liquor [25].

Employing oxalic acid as reductant in sulphuric acid leachant, leaching of lowgrade manganese ore (Mn: 24.7\%) has been carried out by Sahoo et al. [26]. They reported that the concentration of oxalic acid had a strong influence on the extraction of manganese, whereas temperature and leaching time showed a positive effect on the extraction of iron and aluminium. Recovery of Mn (II) from pyrolusite ore was followed by leaching using $\mathrm{H}_{2} \mathrm{SO}_{4}$ as leachant and $\mathrm{H}_{2} \mathrm{O}_{2}$ as reductant [27]. Leaching of manganese oxide ore obtained from Gabon and Xiangxi has been carried out using sulphuric acid and waste tea as reductant. The influence of strength of sulphuric acid, temperature, the concentration of reductant on the leaching process has been investigated [28].

The extraction of manganese from low-grade manganese oxide ores by means of calcium sulphide was analysed by Li et al. [29]. The influence of CaS to ore mass ratio, operating leaching variables, the concentration of $\mathrm{H}_{2} \mathrm{SO}_{4}$ on the rates of leaching of $\mathrm{Mn}$ and $\mathrm{Fe}$ were examined. The leaching percentage was $96.47 \%$ for manganese and $19.24 \%$ in the case of iron under the optimized conditions at a reduction temperature of $95^{\circ} \mathrm{C}$ with $1.5 \mathrm{M} \mathrm{H}_{2} \mathrm{SO}_{4}$ The reductive leaching has also been performed by Haifeng et al. using cane molasses as the reductant in the sulphuric acid medium [30]. Using $1.9 \mathrm{M} \mathrm{H}_{2} \mathrm{SO}_{4}$, leaching percent of $97.0 \%$ for $\mathrm{Mn}, 21.5 \%$ for $\mathrm{Al}$, and $32.4 \%$ for Fe were obtained from low-grade manganese ore. Leaching of manganese from low-grade $\mathrm{Mn}_{2} \mathrm{O}_{3}$ ores by concentrated $\mathrm{H}_{2} \mathrm{SO}_{4}$ (0.9:1 ratio with ore) and subsequent reduction using biomass, sawdust, and straw as reducing agents has been carried out by Sun et al. at $95^{\circ} \mathrm{C}$. The leaching efficiency of $91.8 \%$ was achieved [31].

Leaching of $\mathrm{Mn}$ (II) from Sinai ore ( $\mathrm{Mn}: 8.52 \%$ ) in $\mathrm{HCl}$ has been carried out using $\mathrm{H}_{2} \mathrm{O}_{2}$ as reductant. About $97 \% \mathrm{Mn}$ leaching has been leached using the $0.4 \mathrm{M}$ reductant along with $2 \mathrm{M} \mathrm{HCl}$ maintaining a temperature of $60-95^{\circ} \mathrm{C}$ [32]. Manganese has been extracted from siliceous manganese ores using sulphuric acid and corncob as a reducing agent. In order to reduce the manganese dioxide at low temperature, hydrolysis of corncob has been performed to release glucose in acidic condition. Using this economical and ecofriendly reductant, 90\% manganese has been successfully extracted [33]. On the other hand, Cheng et al. have effectively utilised cornstalk as a reducing agent along with sulphuric acid as a leaching solvent for reduction and roasting of low-grade manganese dioxide ore. Approximately $90.2 \%$ of manganese has been recovered, maintaining the weight ratio of the ore: reductant as 10:3. Polymetallic manganese nodules contain $18 \%$ $\mathrm{Mn}$ along with $\mathrm{Cu}, \mathrm{Ni}, \mathrm{Co}$, and $\mathrm{Fe}$ [34]. Several researchers have investigated the leaching of polymetallic nodules to get $\mathrm{Mn}$ in a substantial amount using reductive acid leaching procedure as reported by Allen et al. [35]. 


\section{b. Solvent extraction}

Chemical separation methods are usually designed to adopt simple procedures in order to consume less amount of solvents with an aim to marginally cut down the waste [36]. The liquid-liquid extraction schemes using modern equipment such as homogenous liquid-liquid extraction (HLLE) have been designed for this purpose [37]. In the hydrometallurgical process, after leaching the ores and scraps, either by precipitation or solvent extraction recovers the metal values. In case of precipitation, due to nearly equal values of solubility products, there are chances of simultaneous precipitation of other metals along with the desired metal. Solvent extraction is a prominent technique for the separation and purification of metals that are not possible using conventional hydrometallurgical processes. In the solvent extraction, the organic phase containing the extracting agent drags the desired metal ion species from the aqueous feed attributable to the formation of a strong hydrophobic complex with higher solubility in the organic phase. For efficient extraction, choice of extractant is a vital factor, and numerous organic extractants are used by different researchers to perform the extraction and separation studies of manganese efficiently as described by Ali et al. and Ahn et al. [38, 39]. The extraction percentage enhanced with the increase in equilibrium $\mathrm{pH}$ of the solution, and the highest separation for both the metals has been achieved with $0.05 \mathrm{M}$ sodium salt of DEHPA. The extraction order of manganese with the three extractants is Na DEHPA $>\mathrm{Na}$ PC 88A > Na Cyanex 272, but a reverse trend was observed for cobalt.

Organo-phosphorus acidic extractants have been broadly in use for the separation and recovery of metal values because of their chemical stability, high solubility in an organic solvent, and high selectivity. Devi et al. [40] reported the extraction of manganese from sulfate solutions employing DEHPA (HR) diluted in kerosene. $\mathrm{MnR}_{2}(\mathrm{HR})_{2}$ and $\mathrm{MnR}_{2}(\mathrm{HR})_{3}$ complexes were proposed to be there in the extracted organic phase with the use of DEHPA and Cyanex 272. Devi and Mishra [41] have studied the extraction of Mn (II) sulphate using Cyanex 302 in kerosene. It has been observed that the rate of extraction enhances at higher $\mathrm{pH}$ and higher Cyanex 302 concentration. Cyanex 302 containing oxygen and sulphur proves to be an efficient extractant for Mn (II). The reaction mechanism of the extraction process is expressed as

$$
M n_{(a q)}^{2+}+\frac{n}{2}\left(R_{2} H_{2}\right)_{(o r g)} \leftrightarrow M n R_{2} \cdot(R H)_{n-2(o r g)}+2 H_{(a q)}^{+}
$$

Biswas \& Rahman [42] have studied the removal of Mn (II) from sulphate-acetato medium with the help of acidic extractant, Cyanex 272 diluted in kerosene. Devi [43] has studied the extraction Mn (II) from acetic acid-acetate buffer medium using two extractants, DEHPA and Cyanex 272, in kerosene. Variation in metal and extractant concentration, influence of $\mathrm{pH}$ and temperature has been investigated on the extraction efficiency of Mn (II). During the extraction, the author has also reported the possibility of separation in the presence of other transition metals like copper and cobalt. It has been observed that by enhancing the extractant concentration and equilibrium $\mathrm{pH}$, the extraction percentage of Mn (II) increases. DEHPA exhibited better extraction proficiency in comparison to Cyanex 272, and 100\% extraction of Mn (II) has been achieved. 
Jouni et al. [44] investigated the recovery of manganese from mixed metal solutions containing cobalt, magnesium, calcium, and sodium by solvent extraction process in sulphuric acid medium taking DEHPA and Cyanex 272 as the extractants. It has been reported that the efficiency of Cyanex 272 has been marginally more than DEHPA, and increased temperature decreased the extraction rate of Mn (II). Filiz [45] reported the extraction of $\mathrm{Mn}$ (II) from the aqueous solution of $\mathrm{HCl}$ media by means of Alamine 336 in m-xylene.

Aoki et al. [46] performed investigation on solvent extraction of manganese in ethylene glycol containing $\mathrm{HCl}$ as an aqueous medium using TOPO as an extractant and cyclohexane or toluene as the diluent. The efficiencies of DEHPA, PC 88A and Cyanex 272 in kerosene have been compared for the separation process of two transition metals such as manganese and cobalt from sulphate solutions. It has been reported that DEHPA is the most appropriate extractant for the separation of manganese from cobalt. The separation of manganese from cobalt and nickel has also been examined with only DEHPA. Separation of manganese from nickel has been possible at high temperatures (40-60 ${ }^{\circ} \mathrm{C}$ ), whereas $23{ }^{\circ} \mathrm{C}$ was found to be the optimum temperature for effective separation of manganese from cobalt [47]. Niroomanesh et al. [48] observed that $97.5 \%$ manganese had been extracted by taking 0.4 M DEHPA at $\mathrm{pH} 3.5$ and O/A ratio of 1 . The stoichiometry of the complex formed after extraction was ascertained from slope analysis as $\mathrm{MA}_{2}$.

Ionic liquids have gained importance as green extractants used in liquid-liquid extraction techniques due to their unique physicochemical properties such as high thermal stability and higher flashpoint. The extraction and stripping of transition metals like Fe and Mn have been performed using Cyphos IL 101 and Aliquat 336 by Ola et al. [49]. From the investigation, it has been found that the extraction ability of Cyphos IL 101 has been higher than Aliquat 336 for Fe (III) in comparison to Mn (II). The extraction mechanism has been explained on the basis of anion exchange taking place between the anions of ionic liquid and $\mathrm{FeCl}_{4}{ }^{-}$and $\mathrm{MnCl}_{3}{ }^{-}$chloro-complexes.

The extraction of Mn (II) along Co (II) and Ni (II) from acidic chloride solution has been examined with variations in the structure of alkyl groups present in the organophosphorous acidic extractants. The pKa values of extractants have a significant influence on the extraction process. Extraction of Mn (II) is adversely affected by increasing the hydrophobicity of the cationic exchanger [50].

Ahmadipour et al. [51] performed the synergistic investigation on the separation of Mn (II) and Zn (II) using a mixture of DEHPA and Cyanex 272 as the extractants by solvent extraction method. It has been recommended that DEHPA/Cyanex 272 ratio of 1:3 in a mixture is suitable for separation of zinc and manganese. Batchu et al. [52] performed the investigation on extraction of Mn (II) from chloride medium where Cyanex 301 and Cyanex 272 in kerosene.On the basis of the slope analysis method, the mechanism for synergistic extraction has been proposed as

$$
M n_{(a q)}^{2+}+(H A)_{2(o r g)}+(H B)_{2(o r g)} \rightarrow M n H_{2} A_{2} B_{2(o r g)}+2 H_{(a q)}^{+}
$$

Hosseini et al. [13] conducted the synergistic separation of Mn (II) and $\mathrm{Zn}$ (II) using a mixture of DEHPA and Cyanex 302 in sulphate medium. Cyanex 302 behaved as a synergist when added to DEHPA in the extraction process, and with this, the separation of zinc over manganese increased. Batchu et al. [53] studied the modeling of the 
extraction equilibrium of Mn from aqueous solutions of sulphate with the help of TBP and Cyanex 301(HA). It has been reported that substantial synergism has been exhibited in the case of extraction of Mn (II) by the combination of two extractants. From the slope analysis method, the stoichiometry of the extracted complex has been formulated as $\mathrm{MnA}_{2} \cdot$ TBP.The use of extractants like Cyanex 302, Cyanex 302, along with Aliquat 336 in toluene, were successful in extracting $50 \%$ manganese at $\mathrm{pH} 4$. The efficiency of Cyanex 301 for extraction Mn (II) was more in comparison to the binary mixture of Cyanex 301 and Aliquat 336 [54]. The synergistic extraction of manganese carried out in chloride and sulphate solutions have also been reported $[55,56]$.

\section{Recovery from secondary resources}

There are several secondary resources such as spent batteries, effluents from steel plants, spent catalysts etc., from which manganese extraction can be exploited. The progress of modern electronic technologies by deriving energy from the battery has given rise to an enhancement in the manufacture of batteries over the last few decades. Manganese recycling is essential to iron and steel production. The metallurgical applications of manganese accounts for the fact that most of it gets consumed along with iron in steel making [57]. In the past few years, numerous hydrometallurgical processes have been operating for the minerals of Mn. From the waste batteries, sludges, industrial wastes, spent catalysts, manganese can be recovered by adopting an economically feasible process like leaching followed by different purification steps. The recycling of manganese from various secondary sources with efficient and economically viable hydrometallurgical processes such as leaching and solvent extraction have been investigated by several researchers. The general procedure for recycling of manganese from spent batteries by a hydrometallurgical process is illustrated in Fig. 3.

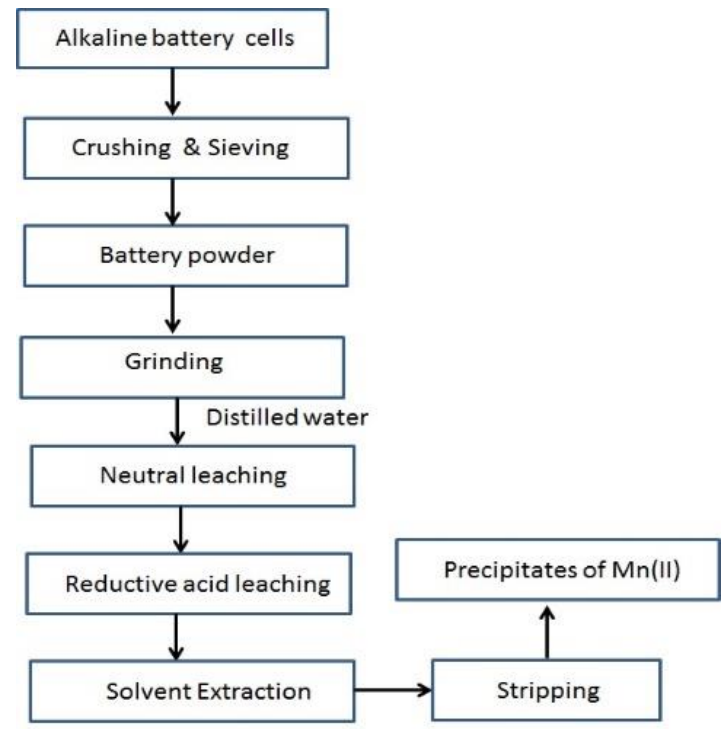

Fig. 3. Flow sheet for recycling of manganese from spent batteries using the hydrometallurgical technique. 


\section{a. Leaching}

Acid leaching process has been adopted for the recovery of zinc and manganese from the spent alkaline $\mathrm{Zn}-\mathrm{MnO}_{2}$ batteries [53]. It has been observed that by increasing the leaching time and reducing agent concentration the leaching efficiency gets enhanced from the spent batteries. Upon mixing $30 \% \mathrm{H}_{2} \mathrm{O}_{2}$ in the $\mathrm{H}_{2} \mathrm{SO}_{4}$, reductive leaching enhanced the extraction efficiency of $\mathrm{Mn}$ (II) from $43.5 \%$ to $97.5 \%$ without influencing the extraction behaviour.

Chen et al. [58] performed reductive leaching using sulphuric acid from spent $\mathrm{Zn}$ $\mathrm{MnO}_{2}$ battery electrode powder containing $30.1 \% \mathrm{Mn}$ and $25.6 \% \mathrm{Zn}$. The selective precipitation using $\mathrm{NaOH}$ at $\mathrm{pH} 13$ has been carried out, and further, the hydroxides get converted to oxides by calcination. The leaching rate of manganese has been reported as $60 \%$. The leaching efficiency of both the metals increased up to $98 \%$ with the use of ascorbic, citric, and oxalic acids as reducing agents.

The extraction and purification of transition metals such as $\mathrm{Mn}, \mathrm{Ni}$, and $\mathrm{Co}$ from spent battery material have been performed with $\mathrm{HCl}$ to carry out a faster and easier leaching process. Sayilgan et al. [59] performed the investigation on $\mathrm{Zn}$ and $\mathrm{Mn}$ by reductive leaching of alkaline spent batteries and zinc-carbon batteries in sulphuric acid or in $\mathrm{HCl}$ medium. The role of oxalic acid as a reductant has been checked. The negative influence of oxalic acid on $\mathrm{Zn}$ leaching in both sulphuric and hydrochloric acid media has been observed. On the other hand, the concentration of both the acids showed a positive influence on $\mathrm{Mn}$ and $\mathrm{Zn}$ extraction.

De Michelis et al. [60] have examined the recovery of $\mathrm{Zn}$ and $\mathrm{Mn}$ from alkaline and $\mathrm{Zn}-\mathrm{C}$ spent batteries using a similar medium as Sayilgan et al.; they have reported that $70 \% \mathrm{Mn}$ and $100 \% \mathrm{Zn}$ extractions have been obtained by reductive leaching taking $20 \%$ pulp density along $1.8 \mathrm{M}$ sulphuric acid, $59.4 \mathrm{~g} / \mathrm{L}$ oxalic acid. The process has been carried for five hours at $80{ }^{\circ} \mathrm{C}$.

A method for leaching spent $\mathrm{Zn}-\mathrm{C}$ battery scraps have been anticipated by [61]. It has been observed that almost $90 \% \mathrm{Zn}$ and Mn have been leached within 30 minutes using sulphuric acid in the presence of sulphur dioxide at $30^{\circ} \mathrm{C}$. Ferella et al. [62] recovered $\mathrm{Zn}$ and $\mathrm{Mn}$ from spent batteries using sulphuric acid/oxalic acid and sulphuric acid/hydrogen peroxide leaching systems. Finally, the oxides of the metals are obtained in purified form and recovered by electrolysis.

Recovery of $\mathrm{Zn}$ and $\mathrm{Mn}$ from zinc-manganese dioxide batteries has been carried out by the leaching process using aqueous sulphuric acid. The effect of leaching time, sulphuric acid concentration, and temperature have been investigated. With the increase in concentration of sulphuric acid, the recovery of $\mathrm{Mn}$ increases [63]. Ascorbic acid, citric acid, and oxalic acid have been used for the reductive acidic leaching of spent alkaline and $\mathrm{Zn}$-carbon alloy battery powders. Leaching has been reported to be high at a temperature of $90^{\circ} \mathrm{C}$. Precipitation of $\mathrm{Mn}$ has been done at $\mathrm{pH}$ 9-1[64]. The leaching of spent $\mathrm{Zn}-\mathrm{C}$ - batteries containing $20 \% \mathrm{Mn}$ has been tested using $\mathrm{H}_{2} \mathrm{SO}_{4}$ and $\mathrm{NaOH}$. The addition of $\mathrm{H}_{2} \mathrm{O}_{2}$ to $2 \mathrm{M} \mathrm{H}_{2} \mathrm{SO}_{4}$ enhanced the dissolution rate of $\mathrm{Mn}$ to $82.2 \%$ at $60{ }^{\circ} \mathrm{C}$, whereas, with $4 \mathrm{M} \mathrm{NaOH}$ at $80{ }^{\circ} \mathrm{C}$, the dissolution rate has been negligible $[65,66]$. Table 3 enlists the summary of recovery of manganese from primary and secondary resources using leaching. 
Table 3. Summary of recovery of manganese from primary and secondary resources using leaching.

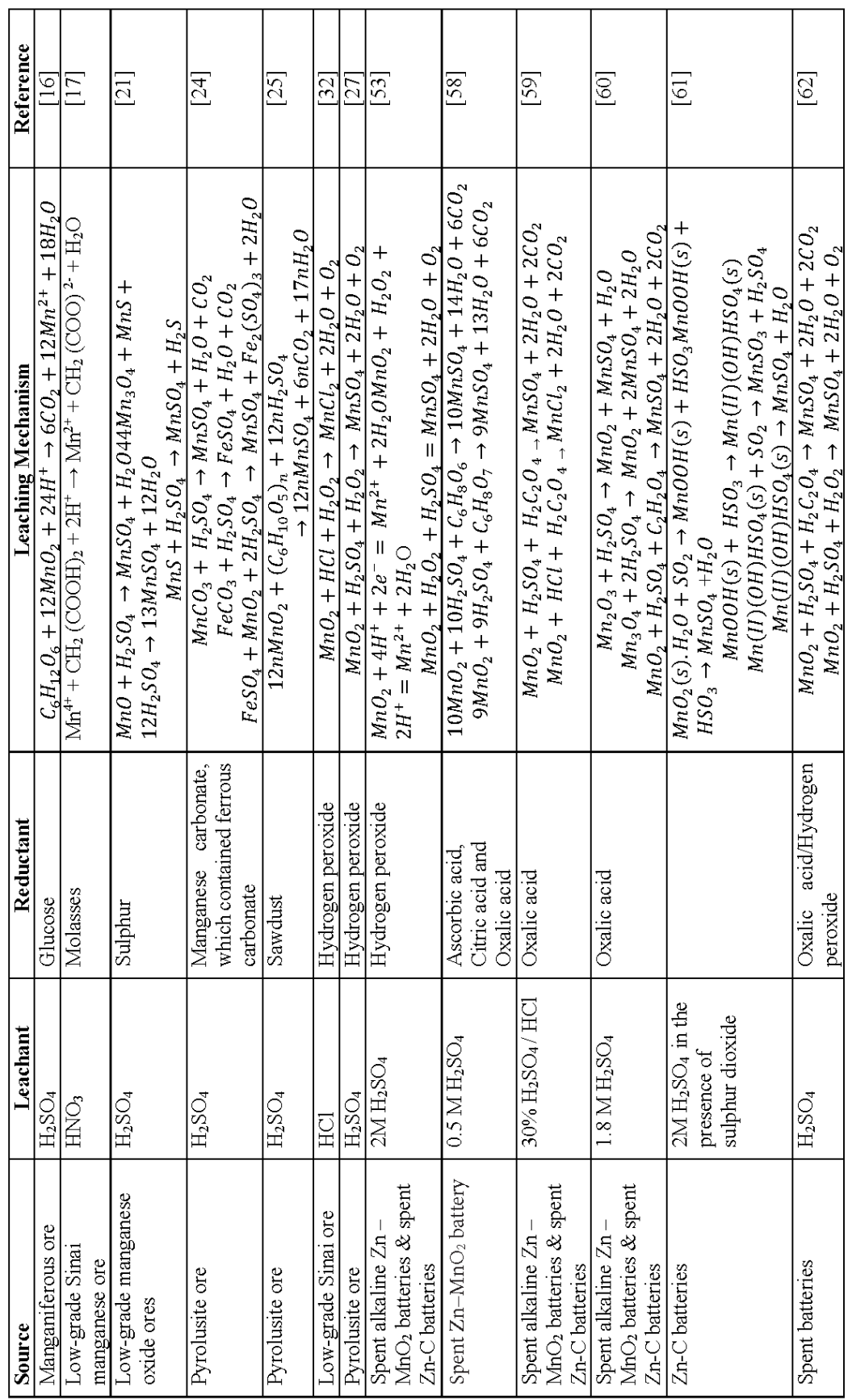




\section{b. Solvent extraction}

The solvent extraction of Mn (II) using DMNPA in heptane was investigated by $[67,68]$. They proposed the stoichiometry of the extracted Mn complex as $\mathrm{MnA}_{2}(\mathrm{HA})_{4}$. The extraction of metal ions such as $\mathrm{Zn}^{2+}, \mathrm{Mn}^{2+}, \mathrm{Co}^{2+}, \mathrm{Cd}^{2+}, \mathrm{Ni}^{2+}$ and $\mathrm{Li}^{+}$were carried out using sulphuric acid and Cyanex 272 as organic phase extractant and the extraction follows the order, $\mathrm{Zn}^{2+}>\left(\mathrm{Mn}^{2+}=\mathrm{Co}^{2+}=\mathrm{Cd}^{2+}\right)>\mathrm{Ni}^{2+}>\mathrm{Li}^{+}$depending on aqueous phase $\mathrm{pH}$.

Li et al. [69] proposed a process for extraction and purification of $\mathrm{Ni}, \mathrm{Co}$, and $\mathrm{Mn}$ from spent battery material in hydrochloric acid. They achieved the best results using hydrochloric acid with a concentration of $6 \mathrm{~mol} / \mathrm{L}$, a reaction temperature of $60^{\circ} \mathrm{C}$, a liquid/solid ratio of 8:1, and a leaching time of $2 \mathrm{~h}$. Salgado et al. [57], studied the recycling of zinc and manganese from spent alkaline batteries with the help of liquidliquid extraction using Cyanex 272(RH) as extractant at $50^{\circ} \mathrm{C}$.

Zhao et al. [70] studied the synergistic extraction and separation of cobalt (II), manganese (II), and lithium (I) from waste cathodic material of lithium ion batteries using mixture of Cyanex272 and PC-88A. Hong et al. [71], adopted solvent extraction techniques to separate $\mathrm{Co}, \mathrm{Ni}$, and $\mathrm{Mn}$ using different extractants like PC88A, Cyanex 272, and DEHPA from leaching solution of $\mathrm{Li}(\mathrm{NCM}) \mathrm{O}_{2}$ secondary battery scraps.

Manganese has been separated from zinc in spent $\mathrm{Zinc}-\mathrm{MnO}_{2}$ dry cells by solvent extraction using organophosphorous extractants. In this study, Mn and $\mathrm{Zn}$ from spent dry cells were recovered through leaching by $\mathrm{H}_{2} \mathrm{SO}_{4}$ or $\mathrm{HCl}$. Spent zinc- $\mathrm{MnO}_{2}$ dry cells have been leached in the presence of $\mathrm{HCl}$ and $\mathrm{H}_{2} \mathrm{O}_{2}$ as reductant. Co-extraction of $\mathrm{Mn}$ (II) with $\mathrm{Zn}$ (II) was increased as free acidity increased using Cyanex 923 as extractant. Loaded organic phase with $\mathrm{Mn}$ (II) was scrubbed with $2 \mathrm{M} \mathrm{HCl}$. Zn (II) stripping needs $5 \mathrm{M} \mathrm{HCl}$. By adjusting the $\mathrm{pH}$ of the raffinate with the help of sodium oxalate, Ibiapina et al. [72], obtained pure manganese (II) oxalate in the form of crystals have been obtained by evaporation of the final solution. The flowsheet of the investigation has been given in Fig.4. 


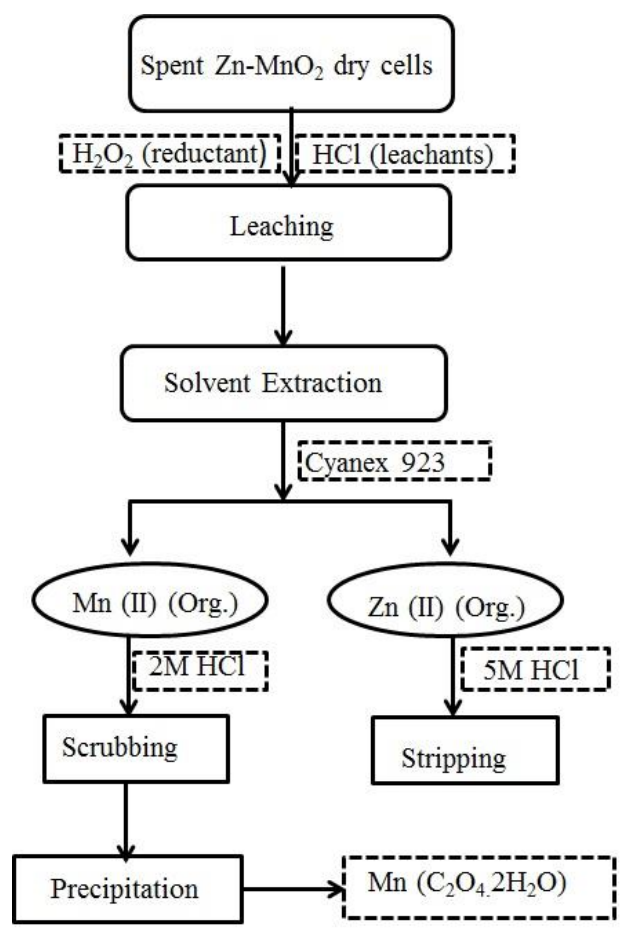

Fig. 4. Hydrometallurgical flow sheet for manganese recovery from spent Zinc-MnO dry cells [72].

The leached solution of spent lithium-ion batteries containing 12,200 mg/L manganese along with elements like $\mathrm{Co}, \mathrm{Ni}$, and $\mathrm{Li}$ have been used for the separation of manganese. The separation studies have been executed using mixture of alkyl monocarboxylic acid and DEHPA. The extraction mechanism of the process has been sketched using the slope analysis method. It has been noticed that with the rise in strength of alkyl monocarboxylic acid in the extractant mixture, the distribution coefficient of the two transition metals, cobalt and manganese, declines. This is because alkyl monocarboxylic acid disturbs the extraction mechanism between DEHPA and cobalt. However, the separation factor of the two metals has been noted to be 4.5. But using continuous counter-current extraction in a mini-plant, manganese recovery from cobalt, nickel, and lithium was feasible. Solvent extraction has been successfully employed for the recovery of $\mathrm{Mn}$ along with $\mathrm{Zn}$ from spent $\mathrm{Zn}-\mathrm{Mn}-\mathrm{C}$ battery leachate. It has been observed that DEHPA has been better in extracting $\mathrm{Zn}$ at $\mathrm{pH}$ 3. Manganese has been completely separated from zinc since a longer extraction time is required for its extraction [73].

Separation of divalent and $\mathrm{Zn}$ from acid -bioleached spent $\mathrm{Zn}-\mathrm{Mn}-\mathrm{C}$ battery has been achieved using DEHPA and Cyanex 272. In this case, extraction of manganese showed dependence on equilibrium $\mathrm{pH}$ and concentration of extractants, DEHPA, and Cyanex 272 [74]. About $95 \%$ of $\mathrm{Mn}$ and $92 \%$ of $\mathrm{Zn}$ have been recovered from leached spent $\mathrm{Zn}-\mathrm{Mn}$ batteries, using solvent extraction technique as reported by Chen et al. [58]. 
A separation scheme for recycling of NiMH batteries using Cyphos IL 101 or Aliquat 336 has been used. In the first stage $\mathrm{Co}, \mathrm{Mn}, \mathrm{Fe}$, and $\mathrm{Zn}$ have been extracted from $8 \mathrm{M}$ chloride solution. Co and $\mathrm{Mn}$ were separated using Aliquat 336 thiocyanate [75]. Solvent extraction to recover $\mathrm{Fe}$ and $\mathrm{Mn}$ from chloride-rich solution using Aliquat 336 and Cyphos IL101 was done by Ola et al. [49]. $\mathrm{MnCl}_{3}{ }^{-}$was extracted, and water was the stripping agent to back extract Mn from loaded Aliquat 336. The selectivity of [P44414] [Cl] was examined for the separation of Co (II) and Mn (II) and was found quite useful in the recycling of NiMH batteries [76]. The separation factors of 400 and 376 were obtained with the $17.8 \% \mathrm{IL}, 25.9 \% \mathrm{HCl}, 56.3 \% \mathrm{H}_{2} \mathrm{O}$ and $18.1 \% \mathrm{IL}, 20.8 \% \mathrm{HCl}$ and $61.1 \%$ $\mathrm{H}_{2} \mathrm{O}$ at $50{ }^{\circ} \mathrm{C}$, respectively. Cyanex 272 and PC 88A have been used for synergistic extraction of $\mathrm{Mn}$ (II) from waste cathodic materials of $\mathrm{Li}$ ion batteries at equilibrium $\mathrm{pH}$ of 4.95 [70].

\section{Conclusions}

This present review demonstrates that the extraction and separation of manganese from its ores, solutions, and post-consumer products involve treatment of the source, leaching, solvent extraction, and separation under variable experimental conditions. From the above discussions, it can be concluded that the use of hydrometallurgical methods in the handling of manganese ores and secondary resources is generally preferred due to low cost and less environmental pollution. Among all the extractants, DEHPA is considered the cheapest, and it is quite selective for the solvent extraction of manganese. Various leaching agents like organic acids, mineral acids, alkalis, complexing agents have been used to solubilize manganese present in battery wastes. For leaching, sulphuric acid was found to be most suitable for manganese dissolution. Organophosphorus extractants like DEHPA, Cyanex 272, and PC88A have been used to recover Mn (II) from spent batteries with the help of solvent extraction techniques. The recent developments in the solvent extraction of Mn (II) can be witnessed through the clarification of reaction mechanism obtained from leaching and extraction kinetics studies.

The intricate techniques are generally in place for the up-gradation of low-grade ores of manganese available in nature. Due to the simplicity in operation and less energy consumption, the hydrometallurgical processes are getting priority in manganese separation and purification segments. There are few reports available in literature in the last decade on the use of green ionic liquids for the separation of manganese, mostly on a laboratory scale. The search for novel technologies using ionic liquids and recovery of metal values from the secondary resources like the end of life products as well as sea nodules on a commercial scale is a future challenge for the metallurgists in the field of manganese research.

\section{Acknowledgment}

The authors express their gratefulness to the authorities of Siksha 'O' Anusandhan Deemed to be University for the inspiration to pursue this review work.

\section{Abbreviations}

EDTA: Ethylenediaminetetraacetic acid

DMNPA: di-2-methyl-nonyl-phosphoric acid

DEHPA: di-2-ethylhexyl phosphoric acid

Cyanex 272:2,4,4-trimethylpentyl phosphinic acid 
Cyanex 302: 2, 4, 4-trimethylpentyl thiophosphinic acid

Cyanex 301: 2,4,4-trimethylpentyl dithiophosphinic acid

PC 88A: 2-ethylhexyl phosphonic acid mono-2-ethylhexyl ester

Versatic 10: Neodecanoic acid

Alamine 336: Tri-n-octylamine

\section{References}

[1] B. Xin, B. Chen, N. Duan, C. Zhou: Bioresource Technology, 102 (2011) 1683 1687.

[2] B. Gupta, A. Deep, P. Malik, S. N. Tandon: Solvent Extraction and Ion Exchange, 20 (2002) 81-96.

[3] J. P. Crow, N. Y. Calingasan, J. Chen, J. L. Hill, M. F. Beal: Annals of Neurology, 58 (2005) 258-265.

[4] A. Bruna: Mine production of manganese in mexico from 2010 to 2018, Chemical Resources, Statista, (2018).

[5] S. Mohanty, S. Ghosh, S. Nayak, A.P. Das: Chemosphere, 172 (2017) 302-309.

[6] V. Singh, T. Chakraborty, S.K. Tripathy: Mineral Processing and Extractive Metallurgy Review, (2019).

[7] D. W. Fuerstenau, K. N. Han: Mineral Processing and Extractive Metallurgy Review, 1 (2007) 1-83.

[8] D. E. Rawlings: Journal of Industrial Micrbiology and Bitechnology, 20 (1998) 268-274.

[9] A. A. Baba, L. Ibrahim, F. A. Adekola, R. B. Bale, M. K. Ghosh, A. R. Sheik, S. R. Pradhan, O. S. Ayanda, I. O. Folorunsho: Journal of Minerals and Material Characterisation and Engineering, 2 (2014) 230-247.

[10] Manganese: resource distribution and production, Asian Metal Metalpedia, (2014) http://metalpedia.asianmetal.com/metal/manganese/resources\&production.shtml

[11] K. Tanong, L. Coudert, G. Mercier, J.-F. Blais: Journal of Environment Management, 181 (2016) 95-107.

[12] S.M. Xara, M.F Almeida, C. Costa, Waste Management, 43 (2015) 460-484.

[13] T. Hosseini, F. Rashchi, E. Vahidi, N. Mostoufi: Separation Science and Technology, 45 (2010) 1158-1164.

[14] S. Ghosh, A. P. Das: Science Report, 8 (2018) 1-12.

[15] S.S. Maryam, G. Vanpeteghem, I.F.F Neto, H.M.V.M. Soares: Waste Management, 60 (2017) 696-705.

[16] M. Trifoni, L. Toro, F. Vegliò: Hydrometallurgy, 59 (2001) 1-14.

[17] T. A. Lasheen, M.N. El Hazek, A.S. Helal, W.S. El-Nagar:International Journal of Mineral Processing, 92 (2009)109-114.

[18] Y. Feng, S. Zhang, H. Li: International Journal of Minerals, Metallurgy and Materials, 23 (2016) 241-246.

[19] D. Hariprasad, B. Dash, M.K. Ghosh, S. Anand: Indian Journal of Chemical Technology, 16 (2009) 322-327.

[20] C. Xie, L. Xu, T. Peng, K. Chem, J. Zhao: Chinese Journal of Geochemistry, 32 (2013) 222-226.

[21] Y. Zhang, Z. You, G. Li, T. Jiang: Hydrometallurgy, 133 (2103) 126-132.

[22] R. Dundua, G. Agniashvili:Proceedings of the Academy of Science of Georgia, a Series of Chemical, 25 (1999) 1-2.

[23] C. Zhang, S. Wang, Z. Cao and H. Zhong: Metallurgical and Research Technology, 115 (2018) 306. 
[24] E. K. Addai, F. Acquah, I. Yeboah, A. Addo: International Journal of Minning and Mineral Engineering, 7 (2016) 18-36.

[25] A. Ekmekyapar, C. Asin, N. Demirkiran, A. Künkül, A. Baysar, K. Ceylan: Russian Journal of Non-Ferrous Metals, 53 (2012) 211-217.

[26] R.N. Sahoo, P.K. Naik, S.C. Das: Hydrometallurgy, 62 (2001) 157-163.

[27] A. A. Nayl, I. M. Ismail, H. F. Aly: International Journal of Mineral Processing, 100 (2011)116-123.

[28] Q. Tang, H. Zhong, S. Wang, J.H. Li, G.Y. Liu: Transaction of Nonferrous Metal Society China, 24 (2014) 861-867.

[29] C.X. Li, H. Zhong, S. Wang, J.R. Xue, F.F. Wu, Z. Y. Zhang: Transaction of Nonferrous Metal Society China, 25 (2015) 1677-1684.

[30] S. Haifeng, W. Yanxuan, W. Fan: Hydrometallurgy, 93 (2008) 136-139.

[31] Y. Sun, G. Fu, L. Jiang, X. Cai: Mining Metallurgy and Exploration, 35 (2018) 215-220.

[32] M.N.El. Hazek, T.A. Lasheen, A.S. Helal: Hydrometallurgy, 84 (2006) 187-191.

[33] S. Ali, Y. Iqbal, U. Farooq, S. Ahmad: Physicochemical Problems of Mineral Processing, 52 (2016) 56-65.

[34] Z. Cheng, G. Zhu, Y. Zhao: Hydrometallurgy, 96 (2009) 176-179.

[35] J.P. Allen, H.L. Abercrombie, D.A. Rice: Mining, Metallurgy \& Exploration, 8 (1991) 97-104.

[36] A. N. Anthemidis, I. S. I. Adam: Analytical Chimica Acta, 632 (2009) 216-220.

[37] A. N. Anthemidis, K.-I. G. Ioannou: Talanta, 80 (2009) 413-421.

[38] M. R. Ali, R. K. Biswas, S. M. A. Salam, A. Akhter, A.K. Karmakar, M.H. Ullah: Bangladesh Journal of Scientific and Industrial Research, 46 (2011) 407-414.

[39] J.G. Ahn, K.H. Park, J.S. Sohn: Material Transaction, 43 (2002) 20169-20172.

[40] N. B. Devi, K. C. Nathsarma, V. Chakravortty: Hydrometallurgy, 54 (2000)117131.

[41] N.B. Devi, S. Mishra: Hydrometallurgy, 103 (2010) 118-123.

[42] R. K. Biswas, M. S. Rahman:Indian Journal of Chemical Technology, 18 (2011) 372-380.

[43] N.B. Devi: Journal of Chemical and Pharmaceutical Research, 7 (2015) 766-776.

[44] P. Jouni, Y.O. Erkki, Recovery of Manganese from mixed metal solutions by Solvent extraction with organophosphorus acid extractants, Lappeenranta University of Technology, 145-147 (2008)

[45] M. Filiz: Hydrometallurgy, 87 (2007) 58-62.

[46] T. Aoki, Non aqueous Liquid-Liquid Extraction of Manganese from Ethylene Glycol Solution with Tri octyl phosphine Oxide, Bulletin of the Institute of Chemical Research, 59 (1981) 191-195.

[47] C. Y. Cheng: Hydrometallurgy, 56 (2000) 369-386.

[48] M. Niroomanesh, M. R. Ehsani, M. Ghadiri, A. A. Shamsabadi, S. Laki: Transactions of the Indian Institute of Metals, 8 (2016) 1563-1569.

[49] P. D. Ola, Y. Kurobe, M. Matsumoto: Chemical Engineering Transactions, 57 (2017) 1135-1140.

[50] K. Omelchuk, P. Szczepanski, A. Shrotre, M. Haddad, A. Chagnes: RSC. Advances, 7 (2017) 5660-5668.

[51] M. Ahmadipour, F. Rashchi, B. Ghafarizadeh, N. Mostoufi: Separation Science and Technology, 46 (2011) 2305-2312.

[52] N. K. Batchu, C. H. Sonu, M. S. Lee: Hydrometallurgy, 140 (2013)89-94. 
[53] M. Buzatu, S. Săceanu, M. I. Petrescu, G. V. Ghica, T. Buzatu: Journal Power Sources, 247 (2014) 612-617.

[54] B. K. Tait: Solvent Extraction and Ion Exchange, 10 (1992)799-809.

[55] F. Wang, F. He J. Zhao, N. Sui, L. Xu, H. Liu: Separation and Purification Technology, 93 (2012) 8-14.

[56] Z. Zhu, W. Zhang, Y. Pranolo, C. Y. Cheng: Hydrometallurgy, 127 (2012) 1-7.

[57] A. L. Salgado, A. M. O. Veloso, D. D. Pereira, G. S. Gontijo, A. Salum, M. B. Mansur: J. Power Sources, 115 (2003) 367-373.

[58] W.S. Chen, C.T. Liao, K.Y. Lin: Energy Procedia, 107 (2017) 167-174.

[59] E. Sayilgan, T. Kukrer, F. Ferella, A. Akcil, F. Veglio, M. Kitis: Hydrometallurgy, 97 (2009) 73-79.

[60] I. De Michelis, F. Ferella, E. Karakaya, F. Beolchini, F. Vegliò: Journal of Power Sources, 172 (2007)975-983.

[61] J. Avraamides, G. Senanayake, R. Clegg: Jornal of Power. Sources, 159 (2005) 1488-1493.

[62] F. Ferella, I.D. Michelis, F. Pagnanelli, F. Beolchini, Recovery of zinc and manganese from spent batteries by different leaching systems, Acta Metallurgica Solvaca, 12 (2006) 95-103.

[63] J. Gęga, W. Walkowiak: Physicochemical Problems of Mineral Processing, 46 (2011) 155-162.

[64] E. Sayilgan, T. Kukrer, N.O. Yigit, G. Civelekoglu, M. Kitis: Journal of Hazardous Materials, 173 (2010) 137-143.

[65] S.-M. Shin, J.-G. Kang, D.-H. Yang, T.-H. Kim, J.-S. Sohn: Geosystem Engineering, 10 (2007) 21-26.

[66] F. Ferella, I. Michelis, B. Michelis, F. Beolchini, V. Innocenzi, F. Veglio: International Journal of Chemical Engineering, 659434 (2010) 1-13.

[67] T. Wang, Y. Nagosa: Journal of Chemical Technology, 77 (2002) 1316-1322.

[68] M. B. Mansur: Rem: Revista Escola de Minas, 64 (2011) 51-55.

[69] J. Li, X. Li, Q. Hu, Z. Wang, J. Zheng, L. Wu, L: Hydrometallurgy, 99 (2009) 7 12.

[70] J. Zhao, X. Y. Shen, F. Deng, F. Wang, Y. Wu, H.Z. Liu: Separation and Purification Technology, 74 (2011) 345-351.

[71] H.S. Hong, D.W. Kim, H.L. Choi, S.S. Ryu: Archives of Metallurgy and Materials, 62 (2017) 1011-1014.

[72] V. F. Ibiapina, J. C. Afonso, R. S. da. Silva, C. A. Vianna, J. L. Mantovano: Quim. Nova, 41 (2018) 770-777.

[73] J.Y. Lee, Y. Pranolo, W. Zhang, C.Y. Cheng: Solvent Extraction and Ion Exchange, 28 (2010) 73-84.

[74] L. Falco, M. J. Quina, L. M. Gando-Ferreira, H. Thomas, G. Curutchet: Separation and Science Technology, 49 (2014) 398-409.

[75] K. Larsson, K. Binnemans: Green Chemistry, 16 (2014) 4595-4603.

[76] M. Gras, N. Papaiconomou, N. Schaeffer, E. Chainet, F. Tedjar, J.A.P Coutinho, I. Billard: Angewandte Chemie, 57 (2017) 1563-1566.

\section{(c) (†) Creative Commons License}

This work is licensed under a Creative Commons Attribution 4.0 International License. 